\title{
Article/Artigo
}

\section{Phlebotomine sandflies (Diptera: Psychodidae) in Governador Valadares, a transmission area for American tegumentaryleishmaniasis in State of Minas Gerais, Brazil}

\author{
Flebotomíneos (Diptera: Psychodidae) em Governador Valadares, área de transmissão de \\ leishmaniose tegumentar americana, no Estado de Minas Gerais, Brasil
}

\author{
Ricardo Andrade Barata ${ }^{1,2}$, Gustavo Fontes Paz $^{2}$, Marcela Cardoso Bastos ${ }^{2}$, Roberta Christiane Oliveira \\ Andrade $^{2}$, Daniela Campos Mendes de Barros ${ }^{2}$, Fabiana Oliveira Lara e Silva ${ }^{2}$, Érika Monteiro Michalsky², \\ Aimara da Costa Pinheiro ${ }^{3}$ and Edelberto Santos Dias ${ }^{2}$
}

\begin{abstract}
Introduction: A study on the phlebotomine sandfly fauna was carried out in an endemic area for American tegumentary leishmaniasis in the municipality of Governador Valadares, in the State of Minas Gerais, Brazil. Methods: Captures were undertaken using HP light traps in four districts, on three nights per month, for one year (from January to December 2008). Correlations between climatic factors (temperature, relative air humidity and rainfall) and the numbers of sandflies collected was observed. Results: 5,413 phlebotomine specimens were caught and were identified as belonging to 12 species. Of these specimens, 2,851 (52\%) were females and 2,562 (48\%) were males. Conclusions: Lutzomyia intermedia predominated (29.9\% of the species caught), thus suggesting that they were responsible for transmission of American tegumentary leishmaniasis, together with L. whitmani, which was also found in the area $(4.3 \%)$. The presence of $L$. longipalpis (11.9\%), the main vector for visceral leishmaniasis in Brazil, is an important finding, which makes rigorous entomological surveillance of the area necessary.
\end{abstract}

Keywords: American tegumentary leishmaniasis. Phlebotominae. Lutzomyia. Sandflies. Governador Valadares.

\section{RESUMO}

Introdução: Um estudo da fauna de flebotomíneos foi realizado em uma área endêmica para leishmaniose tegumentar americana no município de Governador Valadares, no Estado de Minas Gerais, Brasil. Métodos: Capturas foram feitas com armadilhas luminosas HP em quatro bairros, três noites por mês, durante o período de janeiro a dezembro de 2008 . A correlação entre fatores climáticos (temperatura, umidade relativa do ar e pluviosidade) e o número de flebotomíneos coletados foi avaliada. Resultados: Foram capturados 5.413 espécimes de flebotomíneos, distribuídos em 12 espécies, sendo 2.851 (52\%) fêmeas e 2.562 (48\%) machos. Conclusões: Lutzomyia intermedia foi predominante com 29,9\% das espécies capturadas, sugerindo ser a responsável pela transmissão de LTA, juntamente com L. whitmani, que também foi encontrada na região (4,3\%). A presença de L. longipalpis (11,9\%), principal vetor de LV no Brasil, é um dado relevante tornando-se necessário uma rigorosa vigilância entomológica na região.

Palavras-chaves: Leishmaniose tegumentar americana. Phlebotominae. Lutzomyia. Flebotomíneos. Governador Valadares.

\footnotetext{
1. Departamento de Ciências Biológicas, Universidade Federal do Vale do Jequitinhonha e Mucuri, Diamantina, MG. 2. Instituto René Rachou, Fundação Oswaldo Cruz, Belo Horizonte, MG. 3. Centro de Controle de Zoonoses, Secretaria Municipal de Saúde, Governador Valadares, MG.

Address to: Dr. Ricardo Andrade Barata. Dept ${ }^{\circ}$ Ciências Biológicas/UFVJM. Campus JK, BR 367, Alto da Jacuba, 39100-000 Diamantina, MG, Brasil.

Tel: $55383532-1236$

e-mail: ricbarata@hotmail.com

Received in 14/09/2010

Accepted in 14/10/2010
}

\section{INTRODUCTION}

In Brazil, American tegumentary leishmaniasis (ATL) is an important public health problem because of increasing numbers of human cases. The infection can cause mutilating lesions and lead to loss of the capacity to work and even death ${ }^{1}$. Over recent years, the significant increase in deforestation has favored adaptation of vectors to anthropic environments and consequently increased human exposure to the parasite ${ }^{2}$. The circulation of Leishmania in domestic environments has favored the emergence of a distinct profile for transmission of the disease that differs from the classical pattern ${ }^{3}$ and is associated with a wider range of activities.

Nowadays, in the State of Minas Gerais (MG), ATL is present in practically all municipalities, in areas where highways and hydroelectric power stations have been built and where clusters of people have settled ${ }^{4}$. In addition to its continuing presence in old endemic foci in the Atlantic forest and in the Rio Doce and Mucuri valleys ${ }^{5}$, numerous cases have also been reported in urban areas of large and medium-sized cities, such as Belo Horizonte, Montes Claros and Governador Valadares.

Governador Valadares, in MG, is considered to be an endemic area. It had 221 new cases of ATL between 2004 and 2007, and approximately $75 \%$ of the cases were in the urban area. In an epidemiological study in the 1970s, in the municipality of Caratinga, near to Governador Valadares, Mayrink et $\mathrm{al}^{5}$ recorded the presence of Lutzomyia whitmani and $L$. intermedia, which are known to transmit Leishmania braziliensis in southeastern Brazil ${ }^{6}$.

The aim of the present study was to identify the phlebotomine fauna and some aspects of the population's behavior, such as the frequency of presence in peridomestic and domestic environments, seasonal variation of the species implicated as vectors 
for leishmaniasis and the influence of climatic factors on the species density. Through this, better understanding of the transmission cycle of ATL in the municipality was sought, along with correlations between the data obtained and the risk of Leishmania transmission, as support for applying control actions in the area.

\section{METHODS}

\section{Study area}

The municipality of Governador Valadares ( $18^{\circ} 51^{\prime} 12^{\prime \prime} \mathrm{S}$ and $41^{\circ} 56^{\prime} 42^{\prime \prime} \mathrm{W}$ ) is part of the administrative area of Rio Doce valley. The total area of the municipality is $2,349 \mathrm{~km}^{2}$, and it is physically characterized by predominance of hills, with altitude levels ranging from 191 to $1,008 \mathrm{~m}$ above sea level. The climate is classified, according to Koppen, as the AW type (tropical sub-warm and subdry), with a mean annual temperature of $25.6^{\circ} \mathrm{C}$ and mean annual rainfall of around $1,350 \mathrm{~mm}$.

\section{Capture sites}

Systematic captures were carried out using HP light traps ${ }^{7}$ between January and December 2008. Sixteen traps were distributed in four districts of the municipality (Elvamar, Vila Isa, Vila Parque Ibituruna and Village da Serra): two inside homes (domestic areas) and two in areas surrounding homes (peridomestic areas). These districts are characterized as transitional environments between the urban area and an area of environmental preservation. These traps were exposed from 4:00 pm to 8:00 am, for three consecutive nights every month, always in the last week of each month.

\section{Phlebotomine identification}

The taxonomic keys of Young and Duncan ${ }^{8}$ and Forattini ${ }^{9}$ were used for identification of the sandfly species. Specimens with missing or damaged characteristics that impaired identification at the species level were considered to be Lutzomyia spp. Females belonging to the genus Brumptomyia were not identified to the species level.

\section{Climatic data}

Climatic data for the study period were obtained through the website http://www.inmet.gov.br/sim/sonabra/convencionais. php. Average monthly values were used in our study.

\section{Statistical analysis}

The correlations between climatic variables (temperature, air humidity and rainfall) and population density of phlebotomines were evaluated by means of Spearman's coefficient ( $p$-value $\leq 0.05$ ).

\section{RESULTS}

The phlebotomine fauna of Governador Valadares was composed of 12 species: Brumptomyia avellari (Costa Lima, 1932), B. nitzulescui (Costa Lima, 1932), Lutzomyia cortellezzii (Brèthes, 1923), L. intermedia (Lutz \& Neiva, 1912), L. ischyracantha (Martins, Falcão \& Silva, 1962), L. lenti (Mangabeira, 1938), L. longipalpis (Lutz \& Neiva, 1912), L. minasensis (Mangabeira, 1942), L. quinquefer (Dyar, 1929), L. sordellii (Shannon \& Del Ponte, 1927), L. termitophila (Martins, Falcão \& Silva, 1964) and L. whitmani (Antunes \& Coutinho, 1939). A total of 5,413 specimens was caught, of which 2,851 were females (52\%) and 2,562 were males (48\%). The peridomestic and domestic areas accounted for $64 \%$ and $36 \%$ of the specimens caught, respectively. Lutzomyia intermedia was the predominant species, comprising $29.9 \%$ of the total number of phlebotomines collected (Table 1).
TABLE 1 - Phlebotomines captured in HP light traps according to the species, environment and gender, in Governador Valadares county, State of Minas Gerais, from January to December, 2008.

\begin{tabular}{|c|c|c|c|c|c|c|c|}
\hline \multirow[b]{2}{*}{ Species } & \multicolumn{2}{|c|}{ Intradomicile } & \multicolumn{2}{|c|}{ Peridomicile } & \multicolumn{2}{|c|}{ Total } & \multirow[b]{2}{*}{$\%$} \\
\hline & $q$ & $\hat{0}$ & $q$ & $\hat{0}$ & $q$ & $\hat{0}$ & \\
\hline Brumptomyia avellari & 0 & 4 & 0 & 13 & 0 & 17 & 0.3 \\
\hline B. nitzulescui & 0 & 1 & 0 & 0 & 0 & 1 & 0.1 \\
\hline Lutzomyia cortelezzii & 288 & 91 & 532 & 145 & 820 & 236 & 19.5 \\
\hline L. intermedia s.l. & 241 & 248 & 412 & 719 & 653 & 967 & 29.9 \\
\hline L. ischyracantha & 141 & 62 & 292 & 125 & 433 & 187 & 11.4 \\
\hline L. lenti & 17 & 23 & 197 & 217 & 214 & 240 & 8.3 \\
\hline L. longipalpis & 43 & 190 & 61 & 355 & 104 & 545 & 11.9 \\
\hline L. minasensis & 0 & 1 & 0 & 0 & 0 & 1 & 0.1 \\
\hline L. quinquefer & 327 & 123 & 117 & 62 & 444 & 185 & 11.7 \\
\hline L. sordellii & 0 & 0 & 2 & 1 & 2 & 1 & 0.1 \\
\hline L. termitophila & 16 & 1 & 48 & 3 & 64 & 4 & 1.2 \\
\hline L. whitmani & 17 & 42 & 44 & 131 & 61 & 173 & 4.3 \\
\hline Brumptomyia spp. & 7 & 0 & 9 & 0 & 16 & 0 & 0.3 \\
\hline Lutzomyia spp. & 16 & 2 & 24 & 3 & 40 & 5 & 0.9 \\
\hline sub-total & 1,113 & 788 & 1,738 & 1,774 & 2,851 & 2,562 & \\
\hline total & & & & & & & 100.0 \\
\hline
\end{tabular}

The monthly averages for climatic variables, considering rainfall, temperature and relative air humidity, can be seen in Table 2. The correlation between the number of phlebotomines captured and the climatic conditions is represented in Figure 1. All the variables evaluated showed a positive Spearman correlation coefficient in relation to phlebotomine density, but only the rainfall and humidity showed significant values $(\mathrm{p}=0.008$ and $\mathrm{p}=0.007$, respectively), while the temperature variable showed a $\mathrm{p}$-value $=0.064$.

Figure 2 shows the monthly distribution of vector species in the municipality of Governador Valadares. Table 3 displays the monthly distribution of phlebotomines captured in each neighborhood, in Governador Valadares, from January to December, 2008. It was observed that in all neighborhoods located in the transitional area between the sylvatic and urban environments, the number of insects captured was considerable, with greatest success in Village da Serra and Vila Isa, probably due to the presence of domestic animals (dogs, chickens, cows, horses and pigs) next to the sampling sites.

TABLE 2 - Monthly averages for climate variables (temperature, relative humidity and rainfall) in Governador Valadares, State of Minas Gerais, from January to December, 2008.

\begin{tabular}{lccc}
\hline Month & $\begin{array}{c}\text { Temperature } \\
\left({ }^{\circ} \mathbf{C}\right)\end{array}$ & $\begin{array}{c}\text { Relative } \\
\text { humidity }(\%)\end{array}$ & $\begin{array}{c}\text { Rainfall } \\
(\mathbf{m m})\end{array}$ \\
\hline January & 25.3 & 72.0 & 190.4 \\
\hline February & 25.3 & 76.0 & 169.6 \\
\hline March & 25.2 & 77.0 & 74.4 \\
\hline April & 24.9 & 79.0 & 57.6 \\
\hline May & 21.6 & 76.0 & 0 \\
\hline June & 21.3 & 70.0 & 0 \\
\hline July & 19.9 & 65.0 & 0 \\
\hline August & 23.1 & 59.0 & 0 \\
\hline September & 23.5 & 60.0 & 0 \\
\hline October & 26.2 & 58.0 & 0 \\
\hline November & 24.6 & 75.0 & 0 \\
\hline December & 24.4 & 79.0 & 221.4 \\
\hline
\end{tabular}




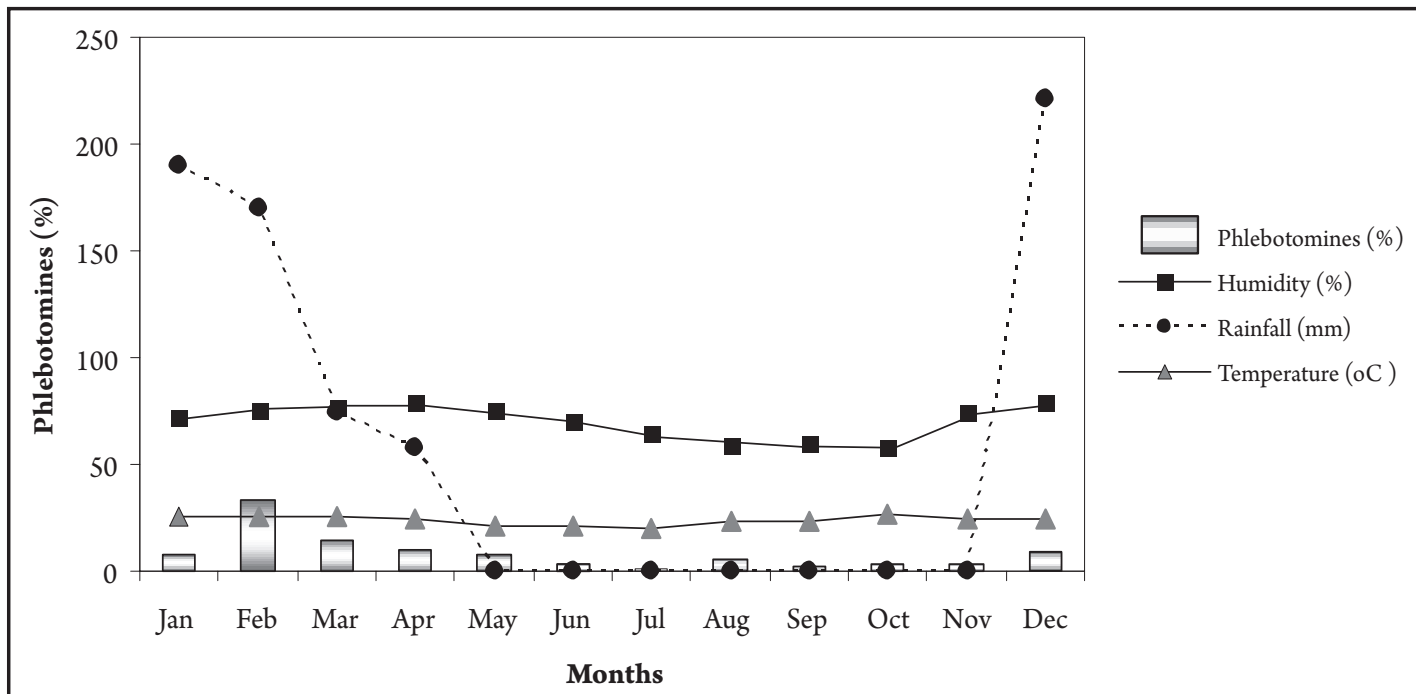

FIGURE 1 - Correlation between population density of phlebotomines and climatic variables (rainfall, temperature and relative humidity of the air) in Governador Valadares County, State of Minas Gerais, Brazil, from January to December, 2008.

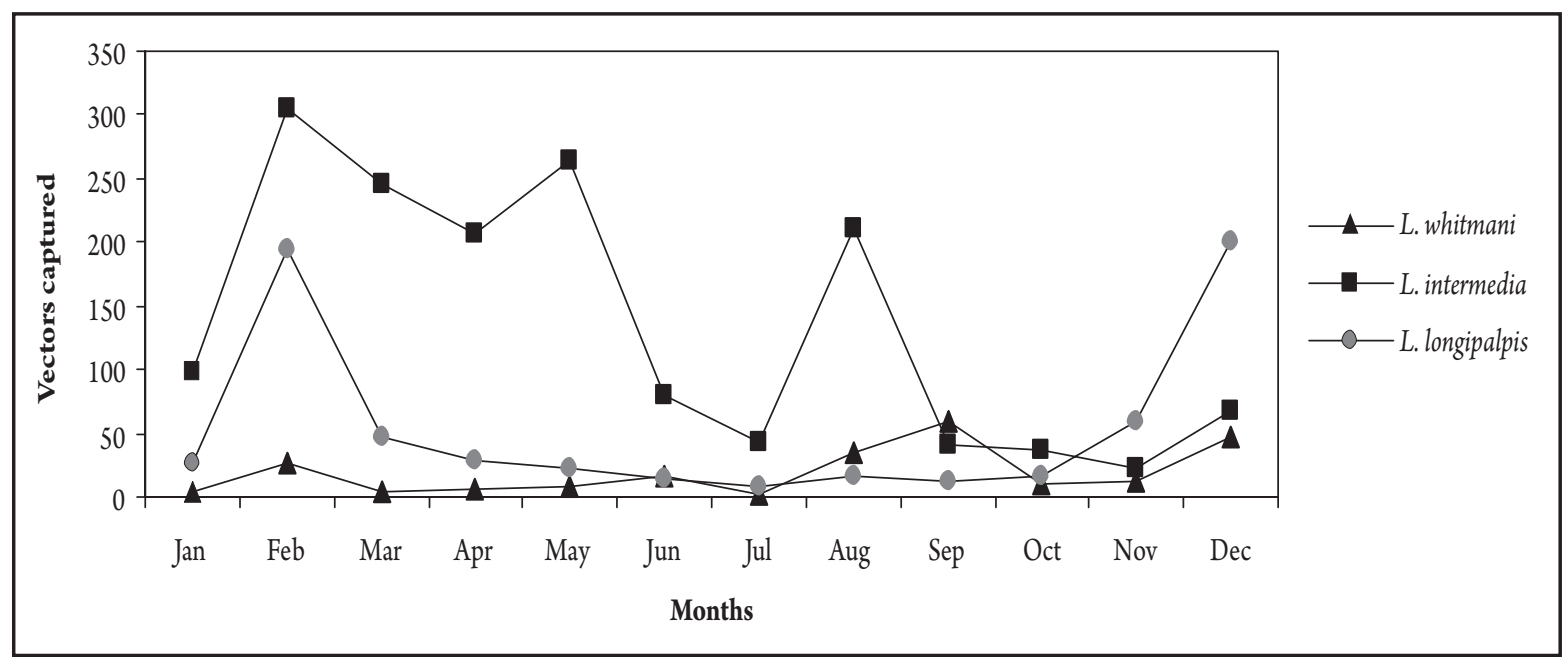

FIGURE 2 - Monthly distribution of vectorial species in Governador Valadares County, State of Minas Gerais, from January to December, 2008.

TABLE 3 - Monthly number of phlebotomines captured in HP light traps according to the neighborhood and gender, in the municipality of Governador Valadares, State of Minas Gerais, from January to December, 2008.

\begin{tabular}{|c|c|c|c|c|c|c|c|c|c|c|}
\hline \multirow[b]{4}{*}{ Month } & \multicolumn{10}{|c|}{ Districts } \\
\hline & \multirow{2}{*}{\multicolumn{2}{|c|}{ Elvamar }} & \multirow{2}{*}{\multicolumn{2}{|c|}{ Vila Isa }} & \multirow{2}{*}{\multicolumn{2}{|c|}{$\begin{array}{l}\text { Vila Parque } \\
\text { Ibituruna }\end{array}$}} & \multirow{2}{*}{\multicolumn{2}{|c|}{$\begin{array}{c}\text { Village da } \\
\text { Serra } \\
\end{array}$}} & \multirow{2}{*}{\multicolumn{2}{|c|}{ Total }} \\
\hline & & & & & & & & & & \\
\hline & $\stackrel{9}{+}$ & 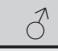 & $\stackrel{9}{+}$ & 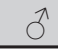 & $\stackrel{?}{+}$ & $\hat{0}$ & 운 & $\hat{0}$ & $\mathrm{n}$ & $\%$ \\
\hline January & 47 & 29 & 125 & 58 & 29 & 8 & 59 & 72 & 427 & 7.9 \\
\hline February & 245 & 166 & 402 & 193 & 164 & 53 & 267 & 303 & 1793 & 33.1 \\
\hline Marchil & 72 & 45 & 143 & 85 & 62 & 24 & 179 & 169 & 779 & 14.4 \\
\hline April & 39 & 29 & 99 & 103 & 32 & 19 & 90 & 154 & 565 & 10.4 \\
\hline May & 19 & 13 & 107 & 70 & 36 & 23 & 72 & 89 & 429 & 7.9 \\
\hline June & 11 & 9 & 35 & 40 & 10 & 11 & 14 & 21 & 151 & 2.8 \\
\hline July & 7 & 9 & 13 & 13 & 7 & 6 & 3 & 8 & 66 & 1.2 \\
\hline August & 11 & 25 & 62 & 89 & 49 & 57 & 1 & 4 & 298 & 5.5 \\
\hline September & 16 & 19 & 18 & 37 & 22 & 25 & 3 & 6 & 146 & 2.7 \\
\hline October & 19 & 20 & 19 & 18 & 25 & 23 & 25 & 8 & 157 & 2.9 \\
\hline November & 8 & 5 & 16 & 8 & 11 & 7 & 28 & 68 & 151 & 2.8 \\
\hline December & 41 & 133 & 17 & 26 & 15 & 14 & 56 & 149 & 451 & 8.4 \\
\hline Total & 535 & 502 & 1,056 & 740 & 462 & 270 & 797 & 1,051 & 5,413 & 100.0 \\
\hline
\end{tabular}




\section{DIscussion}

The results showed that the phlebotomine fauna in the municipality of Governador Valadares is diversified, with some species of epidemiological interest. The presence of L. intermedia and L. whitmani suggests that these species participate as vectors for ATL in this area, as well as in other Brazilian endemic areas ${ }^{10-12}$.

In Governador Valadares, the larger proportion of L. intermedia in relation to L. whitmani indicates that the first of these is a better adapted and more domesticated species, as shown by Souza et al ${ }^{11}$. Females of $L$. intermedia were frequently found in and around homes, while $L$. whitmani was predominantly captured in peridomestic areas characterized by the presence of domestic animals and banana plantations. The presence of both species in these environments increases the risk of Leishmania transmission.

Forattini ${ }^{13}$ studied the seasonal variation of phlebotomines and found that in the hottest and most humid months (December to February), the number of species caught was greater, while in the coldest and driest months (June and August), the population density of these insects became considerably reduced. This was also observed by Dias et $\mathrm{al}^{14}$ and Barata et $\mathrm{al}^{15}$. Our results support this pattern of population distribution, with high densities during periods of high rainfall and high temperatures.

In the present study, the climatic variables of rainfall and relative humidity were statistically significant $(\mathrm{p} \leq 0.05)$. This observation agrees with several other studies that showed that temperature does not present a positive correlation with phlebotomine density ${ }^{14-16}$. In fact, this finding is not a rule, and therefore the climatic characteristics of each region, which are essential for the knowledge of the disease epidemiology, need to be taken into account.

If only the vector species are considered (Figure 2), it can be seen that after an intense period of rains (January), the populations of L. intermedia, L. whitmani and L. longipalpis increased during the subsequent month (February), with a tendency to decrease during the coldest and driest months. In an endemic area for tegumentary and visceral leishmaniasis, Souza et $\mathrm{al}^{17}$ observed that L. longipalpis and L. whitmani tended to undergo noticeable increases in populations after rainfall periods (March and April). This may be explained by the favorable environmental conditions of the microhabitats. Michalsky et $\mathrm{al}^{18}$ showed similar results reinforcing this hypothesis.

Another finding that deserves special attention is the high density of $L$. longipalpis in the districts studied. The presence of the vector for Leishmania infantum makes it necessary to undertake intensive entomological surveillance for visceral leishmaniasis prevention in this area. Moreover, the high phlebotomine percentage inside homes increases the synanthropy index and the possibility of Leishmania sp transmission.

In Brazil, the use of residual insecticides against phlebotomines is feasible in situations of peridomestic and domestic transmission. In the particular case of Governador Valadares, the use of insecticide in the districts studied is possible because they are a transitional area between sylvatic and urban environments. It is therefore recommended that insecticides should be used in the months of March, April and May, with the aim of reducing the numbers of phlebotomines.

\section{ACKNOWLEDGMENTS}

We thank the residents Valéria de Oliveira Ambrósio and Edson Cândido Pereira.

\section{CONFLICT OF INTEREST}

The authors declare that there is no conflict of interest.

\section{FINANCIAL SUPPORT}

This research was funded by Fundação Oswaldo Cruz (FIOCRUZ) and Fundação de Amparo à Pesquisa do Estado de Minas Gerais (FAPEMIG).

\section{REFERENCES}

1. Oliveira MC, Amorim RFB, Freitas RA, Costa ALL. Óbito em caso de leishmaniose cutaneomucosa após o uso de antimonial pentavalente. Rev Soc Bras Med Trop 2005; 38: 258-260.

2. Gomes AC. Perfil epidemiológico da leishmaniose tegumentar no Brasil. Rev Bras Dermatol 1992; 67: 55-60.

3. Campbell-Lendrum D, Dujardin JP, Martinez E, Feliciangeli MD, Perez JE Silans LN, et al. Domestic and peridomestic transmission of American cutaneous leishmaniasis: changing epidemiological patterns present new control opportunities. Mem Inst Oswaldo Cruz 2001; 96:159-162.

4. Furtado T, Vieira JBF. Geografia da leishmaniose tegumentar americana no Brasil An Bras Dermatol 1982; 57:135-140.

5. Mayrink W, Williams P, Coelho MV, Dias M, Martins AV, Magalhães PA, et al Epidemiology of dermal leishmaniasis in the Rio Doce Valley, State of Minas Gerais, Brazil. Ann Trop Med Parasitology 1979; 73:1-14.

6. Peterson AT, Shaw JJ. Lutzomyia vectors for cutaneous leishmaniasis in Southern Brazil: ecological niche models, predicted geographic distributions, and climate change effects. Int J Parasitol 2003; 33:919-931.

7. Pugedo H, Barata RA, França-Silva JC, Silva JC, Dias ES. HP: um modelo aprimorado de armadilha luminosa de sucção para a captura de pequenos insetos. Rev Soc Bras Med Trop 2005; 38:70-72.

8. Young DG, Duncan MA. Guide to the identification and geographic distribution of Lutzomyia sand flies in Mexico, the West Indies, Central and South America (Diptera: Psychodidae). Mem Am Ent Inst 1994; 54:1-881.

9. Forattini OP. Entomologia Médica. São Paulo: Ed. Edgard Blücher. Ed. USP; 1973.

10. Mayo RC, Casanova C, Mascarini LM, Pignatti MG, Rangel O, Galati EAB, et al Flebotomíneos (Diptera, Psychodidae) de área de transmissão de leishmaniose tegumentar americana, no município de Itupeva, região sudeste do Estado de São Paulo. Rev Soc Bras Med Trop 1998; 31:339-345.

11. Souza NA, Andrade-Coelho CA, Vilela ML, Peixoto AA, Rangel EF. Seasonality of Lutzomyia intermedia and Lutzomyia whitmani (Diptera: Psychodidae: Phlebotominae), occurring sympatrically in area of cutaneous leishmaniasis in the State of Rio de Janeiro, Brazil. Mem Inst Oswaldo Cruz 2002; 97:759-765.

12. Saraiva L, Lopes JS, Oliveira GBM, Batista FA, Falcão AL, Andrade-Filho JD. Estudo dos flebotomíneos (Diptera: Psychodidae) em área de leishmaniose tegumentar americana nos municípios de Alto Caparaó e Caparaó, Estado de Minas Gerais. Rev Soc Bras Med Trop 2006; 39:56-63.

13. Forattini OP. Novas observações sobre a biologia de flebótomos em condições naturais (Diptera: Psychodidae). Arch Hyg Saude Publ 1960; 25:209-215.

14. Dias ES, França-Silva JC, Silva JC, Michalsky EM, Paula KM, Macedo CG, et al. Flebotomíneos (Diptera: Psychodidae) em foco de leishmaniose tegumentar no Estado de Minas Gerais, Brasil. Rev Soc Bras Med Trop 2007; 40:49-52.

15. Barata RA, França-Silva JC, Fortes-Dias CL, Costa RT, Silva JC, Vieira EP, et al Phlebotomines sand flies in Porteirinha, an endemic area of American visceral leishmaniasis in the State of Minas Gerais, Brazil. Mem Inst Oswaldo Cruz 2004, 99:481-487.

16. Missawa NA, Dias ES. Phlebotomine sand flies (Diptera: Psychodidae) in the municipality of Várzea Grande: an area of transmission of visceral leishmaniasis in the State of Mato Grosso, Brazil. Mem Inst Oswaldo Cruz 2007; 102:913-918.

17. Souza CM, Pessanha JE, Barata RA, Monteiro EM, Costa DC, Dias ES. Study on phlebotomine sand fly (Diptera: Psychodidae) fauna in Belo Horizonte, state of Minas Gerais, Brazil. Mem Inst Oswaldo Cruz 2004; 99:795-803.

18. Michalsky EM, França-Silva JC, Barata RA, Lara e Silva FO, Loureiro AM, Fortes-Dias CL, et al.Phlebotominae distribution in Janaúba, an area of transmission for visceral leishmaniasis in Brazil. Mem Inst Oswaldo Cruz 2009; 104:56-61. 